\title{
Sap Beetle (Coleoptera: Nitidulidae) Management in Strawberries 1
}

\section{Silvia I. Rondon, James F. Price and Daniel J. Cantliffe ${ }^{2}$}

Sap beetles (Coleoptera: Nitidulidae) are conspicuous arthropods that feed on flowers, fruits, sap, fungi, stored products, decaying and fermenting plant tissues from diverse trees and crops, including strawberries. Sap beetles work in association with yeasts and other fungi causing the fermentation of infested plant parts (Fig. 1). They also are known to transport a variety of microorganisms that cause plant diseases; a few species can behave as predators of various ornamental pests (Dowd, 1991; Dowd and Weber, 1991). Sap beetles are often considered minor pests; however, their main impact is due to the contamination of products caused by adults and larvae.

\section{Description}

Sap beetles, also known as Nitidulids or picnic beetles, like most of the beetles, present complete metamorphosis: eggs, larvae, pupae, and adults. Eggs are white and small; larvae are about the same size as the adults, white, with lateral projections on abdominal segments, presenting a light brown head (Fig. 2); adult strawberry sap beetles are less than $1 / 8$

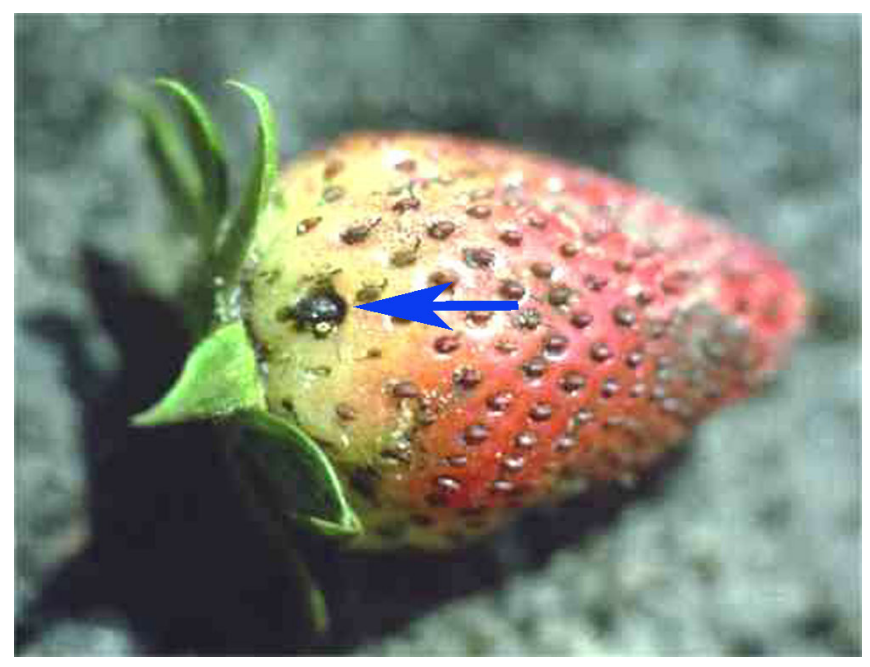

Figure 1. Strawberry fruits infested with a sap beetle adult. Credits: J.F. Price, UF/IFAS, GCREC-Bradenton

inch $(3.2 \mathrm{~mm})$ long to $1 / 4$ inch $(6.4 \mathrm{~mm})$ wide, oval shaped, usually black, brown, or grayish (Fig. 3).

\section{Sap Beetles in Florida}

There are more than 2,500 species of Nitidulid described with more than half of the genera cosmopolite. Six genera are endemic of North America; twenty-one genera have been reported in

1. This document is HS993, one of a series of the Horticultural Sciences Department, Florida Cooperative Extension Service, Institute of Food and Agricultural Sciences, University of Florida. Publication date: October 2004. Please visit the EDIS Web site at http://edis.ifas.ufl.edu.

2. Silvia I. Rondon, adjunct research associate, Horticultural Sciences Department; James F. Price, associate professor, GCREC-Bradenton; Daniel J. Cantliffe, professor and chair, Horticultural Sciences Department, Cooperative Extension Service, Institute of Food and Agricultural Sciences, University of Florida, Gainesville, 32611.

The Institute of Food and Agricultural Sciences (IFAS) is an Equal Employment Opportunity - Affirmative Action Employer authorized to provide research, educational information and other services only to individuals and institutions that function without regard to race, creed, color, religion, age, disability, sex, sexual orientation, marital status, national origin, political opinions or affiliations. For information on obtaining other extension publications, contact your county Cooperative Extension Service office. Florida Cooperative Extension Service / Institute of Food and Agricultural Sciences / University of Florida / Larry R. Arrington, Interim Dean 


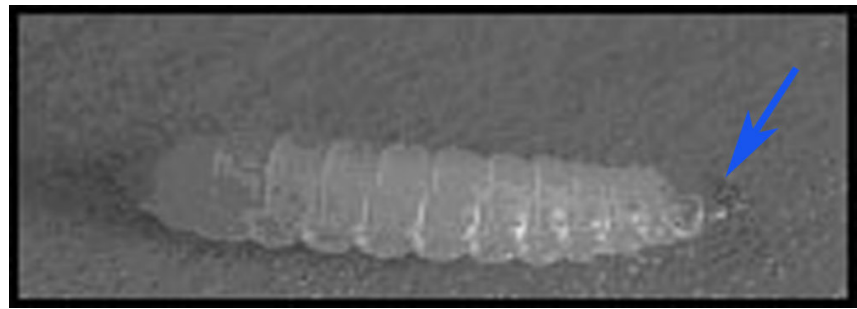

Figure 2. Sap beetle larva. Credits: K. Gray, Oregon State University

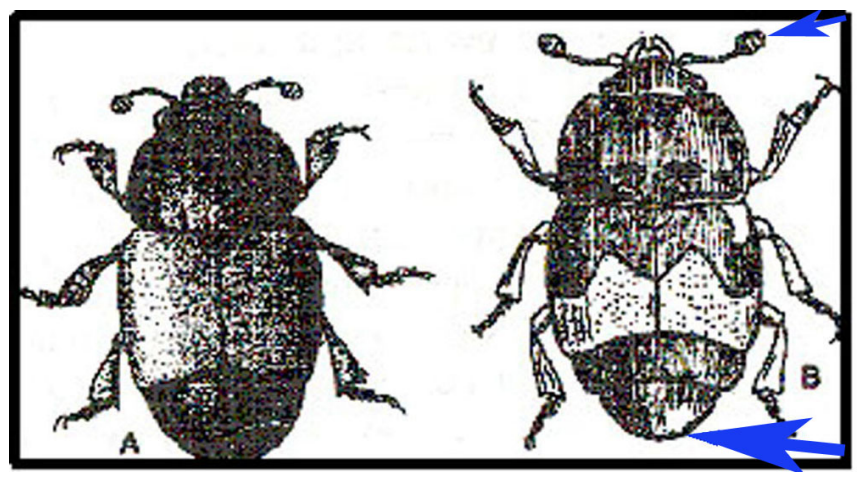

Figure 3. Nitidulids adults can be recognized by the unexposed tip of abdomen heavily sclerotized and antenna distinctly capitate. (A) Carpophilus pallipennis (Say) (2.3 $\mathrm{mm})$; (B) Carpophilus hemipterus (L.) $(2.8 \mathrm{~mm})$. Credits: Arnett, Jr. et al., 1980

Florida including the genera Carpophilus, Stelidota, Glischrochilus, and Epuraea (Parsons, 1943). Potter (1995) indicated that nine Nitidulid species can be found on strawberry fruits in east Hillsborough County (Plant City, FL). These species are:

Carpophilus freemani Dobson, C. fumatus Boheman, C. humeralis (F.), C. mutilatus Erichson, Colopterus insularis (Castelnau), Stelidota geminate (Say), and S. ferruginea Reitter. Approximately $94 \%$ of the Nitidulid population is represented by $H$. luteolus, $L$. insularis, and $C$. fumatus, however, consideration must be given to all. Correct identification should be followed by preventive methods to control damage by sap beetles.

\section{Biology and Ecology}

Sap beetles fly into strawberry fields from wooded areas (overwintering sites) at about the same time berries begin to ripen when temperatures exceed $16^{\circ} \mathrm{C}\left(67^{\circ} \mathrm{F}\right)$. Adult sap beetles attack fruits throughout the growing season ( 2 generations). Longevity of adults last approximately 2 to $21 / 2$ months. A few hours after mating oviposition occurs. After hatching of eggs, larvae burrow inside the berries, feeding on the flesh for approximately $11 / 2$ weeks. Subsequent to that period, larvae fall onto the ground, burrow inside the soil, and pupate. Sap beetles have a wide range of feeding habitats, saprophagous and mycetophagous, feeding on fruits and other plant parts which are ripening or decomposing (Myers, 2001; Peng and Williams, 1990).

\section{Damage}

There are two types of damage inflicted by sap beetles: direct (feeding cavities) and indirect (dissemination of microorganisms). Cavities in berries also serve as oviposition substrate. Larvae inside the berries is usually unnoticed until berries begin to decompose as a result of the damage. Because overripe berries are attractive to sap beetles, damage is often greatest during harvesting when pickers leave large numbers of ripe and overripe berries in the field, row middle, pathways, and ditches (Fig. 4).

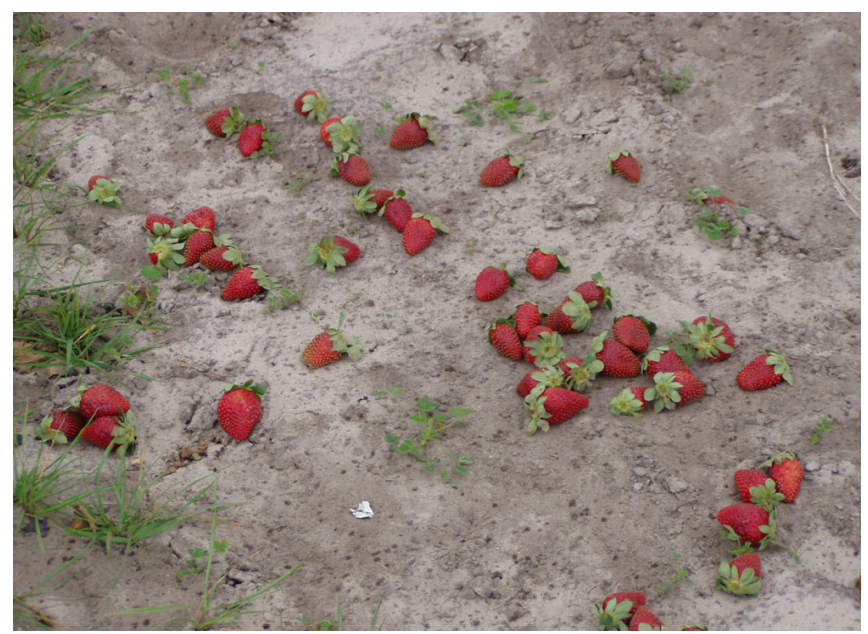

Figure 4. Overripe berries in the field. Sap beetles are attracted to the fermenting fruit. Credits: S.I. Rondon, UF/IFAS, Horticultural Sciences Department

\section{Control}

Sap beetles are not usually economically important in field fresh market strawberries; however, when overripe fruits are harvested for processing, sap beetles may infest the fruit and make the product unmarketable (Price, personal communication). Taking in consideration the ecology of the pest, the following practices are recommended. 
1. If possible, avoid planting strawberry next to woody area.

2. Pick berries before they become overripe.

3. Remove all damaged or overripe fruit from the field, especially in warm to hot weather.

4. Similar sanitation practices should be done with other fruits and vegetables.

5. Picking and placing infested fruit into the row middle should be an alternative reliable method to reduce numbers of adults in the field (Potter, 1995). Fruits decomposed faster in between rows than beetles completing their life cycle, therefore, the beetles cycle will be interrupted. Keep in mind that fermenting berries may attract beetles capable of migrating from long distances (Potter, 1995).

6. For monitoring, place pitfall traps or "trap buckets" of overripe fruit outside field borders to intercept immigrating beetles and reduce numbers in the crop (Price, personal communication).

7. Biological control by means of augmentative releases of nematodes is currently under study (Dowd et al., 1995). In addition, researchers at the University of Ohio are studying the usefulness of Brachyserphus abruptus, a parasitic wasp, to control strawberry sap beetles (Williams et al., 1984).

8. Apply recommended insecticides when conditions justify. Insecticides recommended to control sap beetles include Brigade ${ }^{\circledR}$, Diazinon $®$, and Pyrenone ${ }^{\circledR}$. Some formulations of Malathion $₫$ and Sevin $®$ are registered for control of sap beetles on other crops and are allow to be used on strawberry. Insecticide use is limited by frequent harvests. Frequent and thorough applications should be made during early period of activity. Follow label instructions for best results.

\section{Literature Cited}

Arnett, R.H. Jr, N.M. Downie, and H.E. Jaques. 1980. How to know the beetles. $2^{\text {nd }}$ edition. McGraw - Hill. 414 pp.

Dowd, P.F. 1991. Nitidulidae as vectors of mycotoxin-producing fungi aflatoxin in corn, $\mathrm{pp}$. 335-342. In new perspectives. O.L. Shotwell and C.R. Hurburgh, (eds.) North Central Region. 329 pp.

Dowd, P.F. and C.M. Weber. 1991. A labor serving method for rearing a corn sap beetle, Carpophilus freemani Dobson (Coleoptera: Nitidulidae), on pinto bean-based diet. J. Agroc. Entomol. 8:149-153.

Dowd, P.F., D.E. Moore, F.E. Vega, M.R. Mcguire, R.J. Barlet, T.C. Nelson, and D.A. Miller. 1995. Occurrence of a Mermithid nematode parasite of Carpophilus lugubris (Coleoptera: Nitidulidae) in Central Illinois. Environ. Entomol. 24:1245-1251.

Myers, L. 2001. Sap beetles in Florida. University of Florida, Department of Entomology and Nematology. Featured Creatures. EENY-256.

Parsons, C.T. 1943. A revision of neartic Nitidulidae (Coleoptera). Bulletin of comparative zoology, 92:121-248.

Peng, C. and R.N. Williams. 1990. Pre-oviposition period, egg production and mortality of six species of hibernating sap beetles (Coleoptera: Nitidulidae). J. Econ. Entomol. 23:453-457.

Potter, M.A. 1995. The Nitidulidae (Coleoptera) associated with strawberry in eastern Hillsborough country, Florida. Thesis. University of Florida, Department of Entomology and Nematology. 98 pp.

Williams, R.N., M.J. Weiss, K.V. Miller, and J.J. Werner. 1984. A summary of experiments for control of sap beetles which attack fruit crops. Research circular-Ohio Agricultural Research and Development Center 283:66-68.

\section{Additional Information}

Related Web sites: 
http://creatures.ifas.ufl.edu/field/corn/

sap_beetles.htm

http://strawberry.ifas.ufl.edu/ 